\section{Gloom as Whitehall review predicts cuts in research funds}

\section{London}

A BLEAK future for publicly funded UK research and development is mapped out in the annual review of government expenditure published last week. By $1990-91$, the government plans to cut expenditure on civil research and development (R\&D) by 6 per cent and on defence R\&D by 8.5 per cent from the level of $1986-87$. These cuts do not include those outlined recently for fast reactor research (see Nature 334, 278; 1988). Over the same period, there will be a cut in manpower of about 5 per cent. Nearly 1,500 jobs will be lost in the research councils, 726 in the Ministry of Defence and 51 in civil departments.

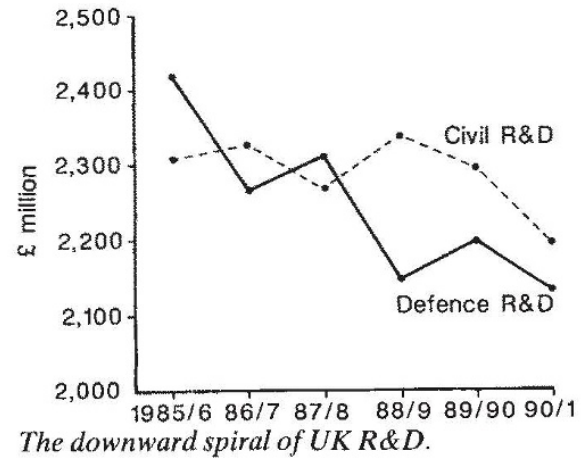

The cuts in civil R\&D in part reflect government policy of withdrawing support from 'near-market' research, which it says industry should pay for. The review shows that public funds for R\&D in industry have been cut drastically. But, with the exception of the chemical and pharmaceutical industry, there has been no significant increase in investment within industry. The review shows that between 1985 and $1986, \mathrm{R} \& \mathrm{D}$ funded by British industry decreased from 66 to 64 per cent. In contrast, during the 1980 s, foreign investment in R\&D in Britain has increased substantially. From 1981 to 1986, R\&D carried out in Britian by overseas-controlled enterprises more than doubled from $£ 331.3$ million to $£ 742.3$ million. During the same period, domestic industry increased R\&D investment by only 55 per cent from $£ 2,324$ million to $£ 3,621$ million. But the government has until now, rejected the use of financial incentives, such as tax relief to encourage investment.

Spending on defence $R \& D$ will be $£ 2,081$ million in $1990-91$, compared to $£ 2,264$ million in $1986-87$. The review shows that in 1986, the proportion of government spending on defence $R \& D$ fell below the 50 per cent mark for the first time, to 49.3 per cent. But these savings are clearly not to be ploughed back into civil $R \& D$ as the science community hoped. Manpower in defence R\&D will

be cut by about 3 per cent to 22,130 and in civil R\&D by about 7 per cent to 20,239 . Cuts are already under way in the research councils, mainly because of reductions in research commissioned by government departments. After several years of reducing staff numbers, the Natural Environment Research Council was forced this year to announce compulsory redundancies for the first time.

Government-sponsored R\&D in Britain fares badly in comparison with other European countries. In 1986, Britain spent 0.62 per cent of the gross domestic product (GDP) on civil R\&D, compared with West Germany (0.97 per cent), France $(0.95$ per cent), Sweden $(0.90$ per cent) and Italy ( 0.67 per cent $)$. Of the countries cited in the review, only the United States $(0.39$ per cent $)$ spends less in proportion to national wealth. But both the United States and Britain spend a greater proportion of GDP on defence R\&D. In 1986, that proportion was 0.60 per cent in Britain compared to the United States $(0.88$ per cent), France $(0.45$ per cent), Sweden ( 0.31 per cent), FRG ( 0.13 per cent) and Italy ( 0.06 per cent).

The Save British Science Society calls for public investment in R\&D to be linked to the national wealth. As research funds dissipate towards 1990, GDP is expected to rise by 8 per cent. The secretary of the society, Dr John Mulvey of the University
Washington

ACADEMIC computer users throughout the United States moved a step closer to nationwide integration last week when the National Science Foundation's upgraded computer network, NSFNET, was inaugurated. With a transmission rate of 1.5 million bits per second, and improved switching technology, the new network should allow researchers throughout the country to work interactively with NSF's six supercomputer centres as well as with databases and other resources, but demand is so great that the capacity of the network may be exhausted in as little as 18 months.

After being put out to tender last August, the contract for the upgrade and maintenance of NSFNET was awarded to Merit Inc., a consortium of eight universities in Michigan that had been successfully operating a state-wide computer network. The expansion of NSFNET by Merit has been done in cooperation with IBM, which helped to develop the switching and routing system, and $\mathrm{MCI}$, a long-distance telephone company, which has supplied digital and fibre-optic land lines. Both

\title{
NSF unveils new computer network
}

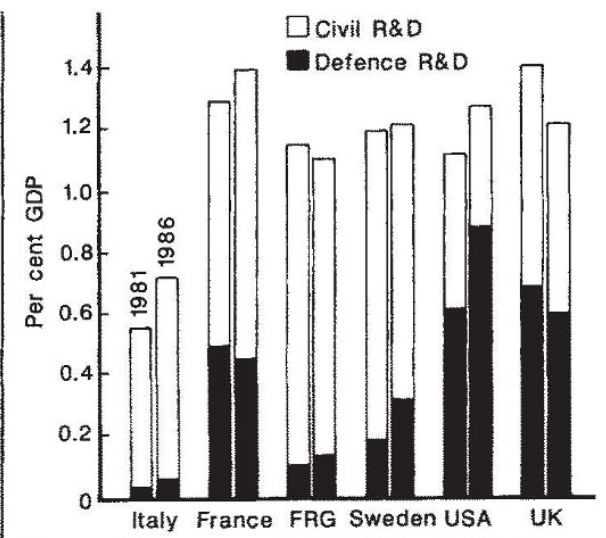

$U K$ wealth increases but $R \& D$ lags behind.

of Oxford, says the situation is worse than most people realize. "If in 1990 we were to spend the same proportion of GDP on civil science and technology as in 1982-83, then expenditure would be $£ 800$ million greater than planned," he says.

Last week, the government advisers on the science budget, the Advisory Board for the Research Councils (ABRC), called for more money to restructure academic science and to reverse the decrease in research carried out in the research councils (see Nature 334, 279; 1988). Mulvey says this request is the minimum required to support the science base.

Until the Public Expenditure Survey in the autumn, the science community is hoping the Secretary of State for Education and Science, Mr Kenneth Baker, will give 'greater priority' to science, as he suggested he might in a letter to the ABRC in February. Christine McGourty

of the companies have provided their services free.

Computer networks in the United States have grown up through a rather haphazard aggregation of regional systems and commercial enterprises, and the resulting proliferation of electronic mail systems and transmission standards has caused as much frustration as communication. Although the expanded NSFNET unifies some of the smaller networks, it is still not easy to move between NSFNET and other national systems such as BITNET and OMNET. But according to Steven Wolf, an assistant director at NSF, plans for further unification are being studied, and NSF has expressed willingness to act as a lead agency in any such programme.

NSFNET was designed to allow an increase in transmission rate by a factor of 30, to 45 million bits per second, to be achieved as the system expands. Wolf expects that users will invent new applications as capacity and reliability increase. The most popular use today, electronic mail, was added as an afterthought to the first networks.
David Lindley 